\title{
CORRESPONDENCE.
}

\section{ANNUITY AND ASSURANCE TABLES FOR THREE LIVES.}

\author{
To the Eiditor of the Assurance Magazine.
}

SIR,-With the view of facilitating the solution of those calculations which are frequently required in practice connected with annuities and assurances on three lives, I constructed some time ago the following tables, and now offer them for publication in your Journal*-namely,

TABLE I.-For determining the Values of Annuities and Assurances on

Three Lives according to the Carlisle Table of Mortality, and showing the Values of the Annuities payable diring the Jorrs Lives. Rate of interest, 3 per cent. Differences of ages, one, one, and two years.

TABLE II.-Ditto ditto. Differences of ages, one, two, and three years. TABLE III.-Ditto ditto. Differences of ages, two, two, and four years.

TABLE IV.-Ditto ditto. Differences of ages, two, three, and five years.

Table V.-Ditto ditto. Differences of ages, two, four, and six years.

TABLE VI.-Showing the Valtue of $f l$ per Annum payable during the

Joint Continuance of Three Lives, and till the Decease of the Longest Liver. Carlisle 3 per cent. Differences of ages, two, two, and four years, and two, four, and six years.

These tables, I understand, are now offered to the profession for the first time. They will therefore, I believe, be found to be of considerable utility in determining those values which are only at present arrived at by approximation, and which undoubtedly can never be so satisfactory as those that are accurately and legitimately ascertained. They have been carefully calculated, checked, and compared, so that they may be safely adopted in practice.

The facility with which such calculations can be performed, as well as all questions relating to contingent survivorship benefits, deferred or temporary, and the accuracy which is invariably secured under the "commutation principle," are well known and understood.

The above tables, although only a fractional part of what might be constructed, are now presented as a specimen of what might be done in this direction. I may take this opportunity of remarking, that the "Joint Life Assurance Tables" which I calculated and sent to you, and which were inserted in your Magazine of July last, were forwarded by me under the impression that no tables were published from which the values there shown conld be obtained without pursuing the ordinary rules of calculation. As these can be deduced from Orchard's Tables, mine will be useful in affording a check upon the results so deduced, and vice versâ. There is, however, this to be said in favour of the tables calculated by me, that they exhibit the values in single and annual premiums at once, without any operation being necessary, and in a form that is not elsewhere to be found.

$$
\begin{aligned}
& \text { I am, Sir, } \\
& \text { Yours truly, }
\end{aligned}
$$

WILLIAM BRAID.

The Scottish National Insurance Company, London, 30th November, 1855. 